\title{
Epiphany
}

Journal of transdisciplinary studies

\section{TRANSLATING POETRY: CAN YOU LEARN IT?}

\author{
Assist. Prof. Dr. Vesna Suljić, International University of Sarajevo*
}

\begin{abstract}
This paper is an attempt to describe the process through which a translator needs to go when translating poetry. Poetry has been part of human civilization since the earliest times; it has derived from the oral tradition and has evolved through centuries into a distinct genre with particular characteristics in terms of structure, form, style, language and other specific features which differentiate it from prose. In the past, poetry has been translated mostly by poets; nevertheless, it seems possible that an individual who has been properly trained and with some practice and passion can produce good quality translation of poetic works. An exercise in translation of a seventeenth-century poem by Andrew Marvell in this paper is based on theory of equivalence to show several aspects of translating, namely the visual, semantic and aesthetic ones, which could pose challenges for translators but which could be addressed and overcome with adequate training. The translator needs to approach a poem and use equivalent means as much as possible to re-create the work by bridging the gaps pertaining to cultural, historical and linguistic codes. The purpose of this exercise is to draw attention to the need of incorporating translating of poetry into the formal translation studies at universities or other institutions dealing with training translators. It also strives to encourage other translators, as well as students and translating instructors to find more poetic works which have been overlooked in the past and which should be translated so that not only the English speakers can revel in their beauty and enchantment.
\end{abstract}

Keywords: Translating poetry, translator training, translation challenges

\footnotetext{
* Corresponding author: Assist. Prof. Dr. Vesna Suljić, International University of Sarajevo,E-mail: vsuljic@ius.edu.ba.
} 


\section{INTRODUCTION}

Translation studies have become increasingly popular worldwide as the demand for qualified translators has been on the rise thanks to more intercultural contacts, media and publishing industry. There are numerous courses specialising in training translators and interpreters to work as medical, legal, scientific, business, administrative or other types of specialised professionals. However, courses offering training for literary translators are less common. Translation of prose literary texts is demanding, time-consuming and requires re-drafting many times so that the final product, once it leaves the translator's desk, should faithfully represent the work written by an author in the source language. Valerie Barnes, who worked for the United Nations as a simultaneous interpreter and translator for decades, wrote: "The finished product has to read as naturally as possible so that the reader would not necessarily know it was a translation" (A Foreign Affair, 2004, p. 122).

Translating poetry, however, is even more challenging. In the past, most translations of poetry were executed by poets who employed their own creative abilities, expertise in both the source and the target language and thanks to their artistic efforts, poetic works have travelled through times. But how can someone who is not a "professional poet" learn to translate poetry? Compared to prose works which more or less imitate human speech in more or less logical and recognisable form and structure (grammar, syntax, lexical choices), poetry combines all of these with some additional features - harmony, musicality, rhythm and style. The translator needs to bridge the gaps pertaining to cultural, historical or linguistic codes existing in the original text as much as possible and in order to do that, the translator needs to use equivalent means to re-create the meaning, the mood, the style and emotions in the translation.

This paper aims to describe the process of translating poetry, some difficulties and challenges posed and how these issues have been addressed. The research material is based on two translated versions of the poem "To His Coy Mistress" by Andrew Marvell. The translation process will be described in the poem which I translated and titled "Stidljivoj mu dragani" (Appendix 3). The second translation titled "Njegovoj sramežljivoj ljubavnici" (Appendix 4) was published by Tanja Bakić (Bakic, 2011). It will be used for demonstrating another translator's approach in addressing 
these challenges. That version will be considered as the final product as it is impossible to assess what went through the translator's mind as she was going through the process of translating this poem.

The analysis will focus on three aspects: the visual (text/form related), the semantic (denotative - content related, and connotative - meaning/ emotion related) and the aesthetic (communicative and artistic) one. Each step will be described and supported by some examples to explain what the challenges were and how they were addressed by each translator. Selfreflectivity is an important part of the translation process and translators should continuously work on evaluating their own methodologies within the selected theoretical framework (Williams, 2013, p. 22).

As Jenny Williams states in her Theory of Translation(2013), it is difficult to single out one general theory of translation that can be applicable to all texts. Theory of equivalence discussed by a number of authors demonstrates the disparity in the idea what constitutes equivalence in translation and how it can be achieved (Williams, 2013, pp. 8-40). For instance, John C. Catford's theory of equivalence proposes that the source and the target language texts should share at least some of the features of style or context. Catford's theory seems suitable to justify "free translations" where the translator recreates the work based on some of the features of the work in the source language. On the other hand, Werner Koller's framework identifies five types of translation equivalence. According to Koller, the translator should maintain the following types of equivalence: denotative (content-related), connotative (meaning- as well as emotion-related), text-normative, pragmatic (communicative function of the text) and formal aesthetic one (Williams, 2013, p. 36). As literary translation cannot be considered literal word-for-word substitution, the hierarchy of priorities must be established first. Writing poetry is part of the creative process which includes not only words organised in meaningful grammatical and syntactical forms but also sounds, images, metaphors and numerous other lexical devices which add to creating a particular mesh of meanings which are open to different interpretations by the reader and translator. The act of reading poetry and then an attempt to convey these subtle nuances into another language is an act of re-creating the work through which the translator interprets and uses particular skills to transmit not only the message but also the enchantment that poetry brings with itself (Miroux, 2010). Translating poetry is "an act of interpreting a text that is variable in form and content" (Venuti, 
2011, p. 128). Therefore, before starting the process, the translator should identify which elements should be retained equivalent, and which could be modified. My hypothesis is that the theory of equivalence in literary translation cannot be applied entirely. According to Williams, this theory "tends to view translation as taking place in timeless, unchanging sphere where absolute rules can be prescribed and which is unrelated to the people and circumstances which require and generate actual translation" (Williams, 2013 , p. 40). As a result, theory of equivalence is applicable in some parts during the process of translation. For instance, it can be predicted that the text-normative equivalence will be easier to achieve, while the aesthetic equivalence will be the most difficult one because the translator will be forced to re-create the work to resemble the original text in its style, mood, tone and sound. The translator's subjectivity and creativity to find the closest equivalent is thus crucial in application of this theory. Moreover, the readers of the translated work will be much different from the readers of the particular time and place when the work was originally created. Therefore, another problem is expected to occur in the translation process - whether to give priority to the norms of the source language or to the target language, which will affect the level of equivalence, namely whether the text is translated faithfully or freely.

\section{Grounds for this research}

Andrew Marvell (1621-1678) was a remarkable figure during the Restoration period in England. Besides being a poet, he was a distinguished scholar and politician. He was a member of Parliament representing Hull in the county of Humberside. During his lifetime, Marvell was best known for his political achievements and for his political satires in prose and verse. In the 20th century, critics began to acknowledge him as an outstanding poet of his time (Abrams, 2000). His poem "To His Coy Mistress" has been acclaimed as one of the greatest poems in English language. Nevertheless, it seems that in the Balkans region only students, educators and scholars in English language departments at universities may be familiar with this poem. I could not find but one translation of this poem in print (Appendix 4). As Gioia suggests, "poems instruct, console and commemorate through the pleasures of enchantment. The power of poetry is to affect the emotions, touch the memory, and incite the imagination with unusual force" (Gioia, Poetry as Enchantment, 2015). I believe that the Bosnian 
speaking community is unjustifiably deprived of access to poetry in other languages due to the lack of translated works. For that reason, I decided to translate this poem and offer it to the Bosnian audience for "the pleasures of enchantment". By going through the translation process of this particular poem, my aim is also to encourage students and scholars to attempt the same, to find and translate other literary gems by other poets which have been hidden in oblivion. I cannot but completely agree with Franck Miroux when he says that

Poetry should be translated to make more and more poems accessible to a non-multilingual readership. Poetry should be translated in order to share the emotion, the vibration of a poem with friends and relatives. It should be translated purely for the sake of the intellectual and physiological pleasure one experiences when helping a poem cross the divide and the threshold between two languages and two cultures. Poetry should be translated, at last, to echo the poet's voice, his poetic voice which reaches far beyond the limits of language. Poetry should be translated, in fact, as if we were the poet himself/herself, to lend him/her our own voice. (Miroux, 2010, p. 108)

\section{An outline of the translation process}

At first glance, poetry differs from prose visually - in the way it is presented on a page - and also aurally - how it sounds when it is read aloud. Any poem contains several components, each of which bears a particular function in the poetic expression, and neither could be separated from each other. Finally, what distinguishes poets from each other is the matter of style which poetic devices are used to create imagery and deep layers of (hidden) meaning.

The first step in the process of translating a poem should be to identify a type of poetry it belongs to, its historical context and the particular features of the poem, its form and structure. This stage in the translation process can be referred to as the visual aspect of equivalence. The visual component of poetry consists of its layout - its form, structure and verse or lineation. In the second stage of the translation process, the translator should do the content analysis of the poem to infer the intended meanings. This information is deemed necessary to meet one criterion of equivalence - to convey the meaning from the source into the target language as 
closely as possible, to make it as equivalent as possible. This stage can be referred to as the semantic aspect of equivalence. It conveys the meaning through lexical choices, grammar and syntax of the verse. The last stage refers to the aesthetic aspect of equivalence. It involves the prosody - the rhythm, meter and rhyme - and also various literary devices. The aesthetic dimension includes how the poem sounds when read aloud. The translator should analyse the meter which the poet utilizes to construe a particular rhythm of the poem, but also the rhyme - ending sounds - which "represent one of the most powerful expressive elements in poetic form" (Gioia, Thirteeen ways of thinking about a poetic line). The translator should recreate the sound as well as the mood, tone and style of the original poem as faithfully as possible and attempt to find the equivalents in the source language. This stage is the most demanding one because the emotional or associative reactions in the reader can be very different due to the cultural and historical differences between these time periods.

The translation process takes time because translators often re-draft their translations before they submit the final version. The translator must ensure that the translation does not contain any material mistakes or mistranslations that could affect the meaning. When translating poetry, the translator may not have the epiphany in the moment of translation, so the process of redrafting and embellishing the translation may take much longer compared to the translation of other prose works. Creative writing courses might be useful since they can assist translators to find expressions and idiolects which may be part of their passive vocabulary but which they may never use themselves. Furthermore, these courses expand the translator's own creative flair and the completed translation may read like something that has been written in that particular language, not translated into it.

\section{The first stage of the translation process: the type of the poem, its historical context and particular features of poetry of that time or place}

"To His Coy Mistress" is a lyrical poem from the seventeenth century England. Many of Marvell's poems were published posthumously in 1681, some thirty years after they had been written, so their dates of composition, including this poem, are not certain. "To His Coy Mistress" is perhaps one of the best known carpe diem poems (Abrams, 2000). This term "carpe diem" ("seize the day") was coined by the ancient Roman poet, Quintus Horatius Flaccus, known as Horace (65-8 BC). The idea of Marvell's poem 
is that youth passes quickly so in order not to be regretful when we get old for things that we hadn't done when we could have done them, do what you can do now - seize the day. The person speaking to his mistress presents arguments in a logical manner: if we had enough time, if we could live much longer than we will, then we could play around, be hesitant and postpone fulfilling our wishes much longer. But, as we do not have that luxury, he urges her to take advantage of the moment and accept his offer and enjoy life to the fullest. He says: "time's winged chariot" is ever racing along, so before they know it, their youth will be gone. There will be only the grave and worms to eat their dead bodies.

Scholars also classify "To His Coy Mistress" as a metaphysical poem. Metaphysical is the term used in relation to metaphysics, the branch of philosophy which examines the relationship between the mind (spiritual, ideational) and the body (physical, sensual). Metaphysical poetry was pioneered by John Donne (1572-1631). Both poets were concerned with the idea of the transcendent - that there exists a reality which the senses may not perceive (Abrams, 2000). This Marvell's poem can be interpreted as a conflict between a bodily desire, a physical love which is constrained and limited by time and social constraints on one hand, and an abstraction of love integrated in the spirit which is timeless and platonic on the other hand. For example, the poet compares love (abstract) to vegetation (physical).

Another feature of style of metaphysical poets in particular is the use of conceit - an extended metaphor using unexpected, almost shocking imagery aiming to confuse, surprise or convince the reader to accept some strong and new idea or the poet's philosophy. In his persuasive style, the poet - the narrator addressing "his coy mistress" - attempts to convince the addressee that life should be enjoyed as much as possible because death is inevitable and "worms shall try / that long preserved virginity". The idea of mortality is not unique to poetry let alone to metaphysical poets. As Gioia posits, "all lyric poetry is directly or indirectly about mortality. The reason we feel the overwhelming force of a particular moment is that our lives are finite" (Poetry as Enchantment, 2015). However, he continues, "genuine poetry always grows out of our basic existential dilemma - our mortality. Our minds have the ability to reach across time to scan the past and ponder the future, but our bodies die" (Poetry as Enchantment, 2015). Marvell seems to be on the same note: if the time was endless and we remained young and vigorous, it would not matter how long the courtship would last. Albeit, our 
lives are finite and we cannot stop the passage of time so we should take any chance to enjoy the pleasure of life now.

\section{The visual components in translation}

Both translated versions of this poem followed the text-related principle of equivalence very closely. As the visual component rests on the layout of the poem on the page and on its form, it seemed it would not pose a particular problem to transfer it into another language. "To His Coy Mistress" is a 46-lines long poem in English and the Bosnian translation follows the same number of lines. The poem consists of three units of thoughts divided into three stanzas of unequal length $(20-12-14$ lines $)$ in the source language, which can be applied in the target language as well. It follows rhetorical principles of argumentation. In the first part, the poet draws on the logos - reasoning - and presents his arguments by describing the hypothetical situation: what would be if it could be. In the second part, the poet contrasts the hypothetical with the reality and combines logos with pathos - attempting to produce an emotional impact on the reader. In the third stanza, the poet draws on ethos - his own authority of "someone who knows" and combines it strongly with pathos as he suggests what should be done at present time. Therefore, applying the structure of these three units of thoughts separated by logical development of argumentation should not be challenging for the translator. Both translators followed the form and structure of the original by dividing the poem into three separate stanzas. However, Bakić shortened the last stanza and omitted four lines in the translation. Another challenge in relation to the visual component occurred as the number of words in each line in the target and in the source language is different, so neither translation offers the complete visual equivalence.

\section{The second stage of the translation process: the content analysis}

The second step in the translation process should include identifying the layers of meanings in the poet's thoughts. In the first stanza of "To His Coy Mistress", the poet praises beauty of his "mistress" and offers a number of hypothetical situations when time would not be an issue and when they could show their love and affection at different places - those close to home, as is the river Humber in Hull where Marvell lived, and those far away, as is the Ganges river in India. The notion of endless time is reflected 
in some Biblical references, from the flood when Noah escaped in his arc to different ages in human history, concluding with "the last age" (in eternity, the passage of time would not be measured because it would not matter anymore). Like other metaphysical poets, to prove his point, the poet uses a number of exaggerations.

In the second stanza, the poet returns to reality still making some references to distant times expressed in classical mythology. For example, "the time's winged chariot" refers to the god Apollo in the ancient Greek myths who rides his chariot from east to west. However, the poet also provides a gory picture of human mortality, decay and vainness, showing how having any human-imposed constraints are futile and worthless.

The change is indicated in the third stanza when the poet emphasises the moment - "now" - and immediately continues with the urge to rectify the futility of abiding by the rules of society when faced with the inevitability of dying - and suggests the solution which comes as the effect of not being able to live eternally in this world - using an adverb to demonstrate the logical result of such assumption - "therefore". From this moment on in the poem, the poet reiterates the effects the passage of time has on humans and re-emphasises his point, which is one of the features that marks carpe diem poetry.

\section{The semantic components in translation}

Denotative and connotative equivalence between a source and a target language depend on lexical choices and the structure of both the source and the target languages - their grammar and syntax. The poet is the one who chooses what to say, how to say it, which language structures to use. The poet can do it spontaneously, as he or she feels, or the poet may make conscious efforts to make it as simple or as intricate as he or she finds it fit. The translator, however, must re-create that process in another language and find suitable words, phrases, expressions and incorporate them in the linguistic structure of the target language so that the translation reads as if it were composed in that language. The transfer of meaning must look and sound as natural as possible and this is a difficulty that the translator must cope with. 
The translator must make a choice whether to give priority to the source language norms and thus produce an adequate translation, or to the target language and produce an acceptable translation. Both translators of this poem opted for the option to produce an acceptable translation and applied the target language norms. There are some similarities on grammaticalsyntactical levels between the source and the target language. For instance, it is possible in both English and Bosnian languages to express hypothetical situations with corresponding grammatical structures, or to use most adverbs, adjectives, conjunctions etc. in the same manner. The problem which occurs in translation is related to the grammatical noun gender - in Bosnian there are three noun genders - masculine, feminine and neutral which also have to be congruent with the adjective in respect to the number (singular-plural) and noun case (there are seven different ones that have different forms in either singular or plural). Similar problems occur with verbs - there are fewer tenses in the Bosnian language in respect to the English, and each tense also has different aspects (active, passive, static or continuous) which does not occur in English in the same manner. As this particular poem does not offer too many varieties in terms of the use of tenses, the translation challenge seems surmountable. The problem of priority given to the language was solved by both translators in favour of the target language. Tenses were adequately translated and the nounadjective combinations are congruent and in accordance with grammatical rules of the target language, which makes both translations acceptable.

The title itself is ambiguous for several reasons. First of all, the wording "To His Coy Mistress" sounds as if someone is addressing a note which will be delivered by someone else on his behalf. It seems as if a poem is enclosed in an envelope containing a letter - a poem - which the addressee will read and know who wrote it. The poet writes the title in the third person - an invitation to the lady to accept his offer - because he might not have the courage to say it openly in her face. Considering that the poem was written in the second half of the seventeenth century and that the poet was also a member of the upper class and had connections with members of the Parliament, politicians and other dignitaries, it seems viable that this kind of communication was practised. Another interpretation of the title is that the poet is talking to the lady in the first person but on behalf of someone else (that is why "To His Coy Mistress appears in the title), using the other person's words. In case the poet was writing a poem on somebody else's behalf, he gave it to that person so that this other person could present it 
to the lady as his own work. Or, another possibility is that the poet felt that he had already appropriated the woman he wrote the poem to as "his own" in his thoughts and mind, so he was exposing his inner talk to her in writing. To translate this small but ambiguous and unusual segment in the title - "to his" - into Bosnian, I opted for an unstressed possessive adjective inserted between the first word ("coy") and the last one ("mistress") which distracts attention from "to his" to "coy" and "mistress". Rules for syntactical structure of the Bosnian language allow for changing word order without losing the meaning. Therefore, in the syntax of the translated title the principle of optional equivalence was used. Bakić, however, followed closely the principle of equivalence in the title and selected the same word order as in the source language.

Lexical choices and their combinations are features which mostly define the author's style and the style of his time. In accordance with Otto Kade's classification of lexical equivalence (Williams, 2013, 35), translators can apply four types of equivalence: total equivalence (when a lexical choice in the target language corresponds completely in meaning and function to a lexical item in the source language); optional equivalence (when a translator has a number of possibilities to choose from the target language, depending on the context); approximate equivalence (where one possible lexical choice in the target language covers only part of the meaning in the source language); and nil equivalence (when there is no lexical choice in the target language that corresponds to the target language). Another possibility is natural equivalence defined by Pym as "reproducing in the receptor language the closest natural equivalent of the source-language message" (Williams, 2013, p.39).

In translation of this poem, both translators applied different types of equivalence, namely optional, approximate and natural equivalence, depending on the context and the number of lexical choices and corresponding meanings in both the source and the target language.

Historical and cultural contexts determine the translator's lexical choices. The meaning of the word "mistress" was probably ambiguous in the time when Marvell composed this poem, and its polysemy continued into the twenty-first century. The word entered the Middle English linguistic corpus from Old French maistresse, feminine noun derived from the masculine maistre meaning "master" (Cambridge Dictionary). In Marvell's time, the 
word "mistress" carried several meanings: from a lady of the house (in contrast to her husband - a "mister"); a woman with power of control; a woman from the noble class; to a female lover (a woman who has a sexual relationship with a man who is not her husband); a courtesan; a woman loved and courted by a man; or it was simply a title of a married woman, i.e. Mrs. As the poet is trying to seduce the woman to have a love affair with him (which she seems to be avoiding because she is "coy", meaning "shy" or "modest", but also "hesitant" to accept his advances based on the strict patriarchal values imposing that a girl - if the addressee is a girl must remain a virgin until marriage), it can be concluded that the meaning of the word "mistress" could therefore be associated with "a woman loved and courted by a man". An affectionate noun - "dragana" in my translation refers to that last interpretation of the meaning and corresponds to the optional equivalence.

Bakić chose the word "sramežljivoj" which is synonymous to "stidljivoj" ("coy"); however, the "mistress", translated as "ljubavnici," bears the connotation of "a female lover (a woman who has a sexual relationship with a man who is not her husband)". As there are a number of meanings in both the source and the target language, the principle of natural equivalence was applied in this instance.

Another example of application of optional equivalence applied by both translators is in: "two hundred [years] to adore each breast", where I translated as "i po dvjesto da se svakoj dojci divim" and Bakić translated as "dvjesto godina da mi je da grudi ti grlim".

Furthermore, both translators re-created the poem to convey similar meanings using different lexical choices, but only approximate equivalence could be achieved. Interpretation of Marvell's "then worms shall try / that long-preserved virginity" is in my translation expressed through euphemism: "crvi da se slade / predugo čuvanom tvojom nevinosti", while Bakić opted for a stronger image referring to the horror of decay: "crvi će zagmizati - i tvoju će dugo čuvanu nevinost proždrati”.

As it can be seen from these examples, connotative equivalence referring to the emotional and associative response in the reader (in this case, the translator) could not be achieved. Translators had similar approaches but the final result was different based on their individual interpretations of the 
source text and lexical options in the target language.

\section{The third stage of the translation process: Aesthetic components}

Artistic dimension is that which distinguishes translated literary works and where the translator's creativity is outside the formal translation equivalence. Translators should study prosody and ascertain whether the acoustic and lexical choices render the meaning as well as the tone and mood of the poem. Meter and rhyme add to the aesthetics of poetry through musicality and harmony, through the sound and flow of thoughts. In this poem, Marvell uses iambic tetrameter (syllables distributed in four iambic feet) in accentual-syllabic verse which is a common metre in English lyrical poetry of his time. "To His Coy Mistress" is written in couplets and mostly masculine rhyme is used (AA, BB, CC and so on). There is an exception in the second stanza, where a regular couplet is inserted between lines 23 and 27 which rhyme ("lie" and "try"), as well as between lines 24 and 28 in which the poet uses a feminine rhyme ("eternity" and "virginity") for the emphasis and change of rhythm. So, the rhyming scheme in lines 23-28 is as follows: $\mathrm{AB} / \mathrm{CC} / \mathrm{AB}$.

In order to make the poem musically appropriate to the Bosnian language, I opted for the modification of the meter and the type of rhyme. The Bosnian language, although accentual, is also a tonal language with different length and sound of stressed syllables - some are short or long with a rising tone, and some are short or long with a falling tone. For that reason, a consistent use of a particular metric foot, for instance an iamb or a trochee, seemed quite impossible if I wanted to convey the meaning as faithfully as possible. Therefore, instead of applying Marvell's choice, I chose the French alexandrine, the meter that was quite popular during the Renaissance with poets from Dubrovnik region, and which was also used in the Balkans region by Croatian and Serbian poets during the 19th and 20th century (Lešić, 2005, pp. 220-232). Since Bosnian is quite similar to either of these two languages, I thought that the French alexandrine, a twelve-syllabic meter with a caesura after the sixth syllable, would be appropriate (www. britannica.com/art/alexandrine). Using this meter sounds more melodic and more natural when read aloud in Bosnian than Marvell's iambic tetrameter.

The rhyming scheme in couplets did not pose too many problems (AA, BB and so on) and I also closely followed the change of rhyme occurring in 
lines 23-28 (AB/CC/AB). However, due to the different stress in words in both languages, it was not feasible to imitate the masculine/feminine rhyme pattern since most polysyllabic words in Bosnian language do not have the stress on the last syllable. For this reason, formal aesthetic equivalence was not possible.

The rhythm of the poem in the first stanza of the original poem was quite regular, with an enjambment in lines 3 and 4 ("and think which way/to walk, and pass our long love's day"), which was also used in lines 23/24, $26 / 27$ and 28/29. In translation, the enjambment was also used in almost the same lines to keep the flow of thought which would not have the singing quality (eg. in lines 3/4: "O danima ljubavi mogli bismo sjesti/ I smišljati gdje i kako ih provesti.") However, the enjambment was also used in the translation where the line of thought could not be finalized with the approaching rhyme. For example, in the last couplet in the first stanza: "For, lady, you deserve this state, / Nor would I love at lower rate", in the Bosnian translation it reads like this: "Jer to, gospo draga, zaslužuješ i ja / Te volio manje od tog ne bih, nikada".

In the second stanza, the poet used enjambments more frequently, which decreases the musicality of the stanza as the rhyme does not get accentuated and the message continues into another line. The sound effect is that the given statements sound more like prose; they are more serious and advicedriven, compared to the lyrical, poetic expression of fun and enjoyment expressed in the first stanza. The overall impression is that the rhythm and pace of the whole poem changes from a playful, walking pace in the first stanza, to the slow, mournful pace in the second one, which suddenly accelerates and becomes a rapid, moving, rushing, almost running pace towards the end of the poem. This change of pace affects the rhythm of the whole poem also when translated into Bosnian.

Bakic also did not follow the strict rhythm and meter scheme, and the length of lines in her translation varies from 12 to 14 syllables throughout the poem. The rhyming scheme is $\mathrm{AA} / \mathrm{BB} / \mathrm{CC}$ without the change in rhyme in lines 23-28. Furthermore, lines 40-44 were completely omitted. The change of the rhythm and pace is notable and use of enjambent adds to the creation of that change. 


\section{The stylistic components}

The most difficult part in translating poetry, in my opinion, is rendering the author's style, mode and mood. Andrew Marvell lived and wrote in the second half of the seventeenth century. The English language has changed a lot since then, but despite these changes, mostly occurring in different spelling or different use of some words back then and nowadays, most texts written in that period are still comprehensible and widely read. For instance, the beginning of the original version of „To His Coy Mistress“ reads like this:

Had I but world enough, \& tyme, This Coynesse, Madam, were noe Crime.

I could sitt downe, \& thinke, which way To walke, \& passe our long-loves day. (British Library, 2020)

Different spelling of words "time", "coyness", "no", "sit down", "think", "walk", "pass" does not interfere with the meaning and the 21 st century reader can easily grasp the meaning of all the words in this example.

The Bosnian language, on the other hand, has undergone significant changes in all linguistic aspects - from the basic form of words to spelling, grammar and syntax. As I am not familiar with the seventeenth-century-spoken or written Bosnian language, and as I also assume that most of potential readers of this poem in translation would experience similar difficulties, I decided to adapt the language to the contemporary Bosnian but with some oldfashioned expressions to give the translation a flair of the past. Yet, in doing so, I tried not to compromise the meaning. I was led by Gioia's advice how can poets be heard - through reading, public performances and through translation (Can Poetry Matter, 2020). Therefore, my aim was to make this poet heard and understood by the contemporary readers. Bakić has also used modern-day language, with occasional shift to some traditional poetic expressions. In both cases the principle of pragmatic equivalence was used to communicate the message. By using the contemporary language devices both translators also applied the principle of optional equivalence.

Poetic diction distinguishes poets from each others and the translator should aim at preserving particular poetic style, imagery and use of poetic 
devices to create a similar atmosphere, mood and tone of the poem. When translating this poem, I endeavoured to find expressions, similes, metaphors and other devices to describe the feelings and the imagery in the poetic environment which Marvell created. It was difficult to find the word-for-word equivalence so some words have been omitted or changed. Bakić also opted for some creative additions to the original. Moreover, some lexical ambiguity was translated differently by both translators. For instance, Marvell's "For, lady, you deserve this state / Nor would I love at lower rate" was translated as "Jer to, gospo draga, zaslužuješ i ja / te volio manje od tog ne bih nikada" in my case, while Bakić translated it as "Jer ti, Damo, zaslužuje ovu državu, / Tebi ja dao bih svu na svijetu slavu”. The image of grave expressed by Marvel as "marble vault" was translated as "mramornoj škrinji" in my translation and as "mermerni svod" by Bakić. In some lines, two completely different translations occurred, creating two very different images. For example, Marvell's "Now therefore, while the youthful hue / Sits on thy skin like morning dew" was translated as "Stoga, gospo, dok boje mladosti tvoje / K'o jutarnja rosa na licu ti stoje" in my translation, while Bakić translated it as "Zato, hajde sada dok sjekira mala / U krilu klati ti se k’o rosa tek što je pala".

As it could be seen from the number of examples, the visual, lexical and acoustic dimensions in a poem are linked with each other to create the idea of unity. In the translation process, these dimensions have to be analysed separately and then connected to re-create the unity of form, structure, thought and artistic expression. Translators of literary works not only convey the meaning, but also all other layers pertaining to the text written in the source language - cultural nuances, stylistic devices, traditions, customs, anything that the author expressed and implied in the original text.

\section{Why should translating poetry be studied?}

The translation exercise which has been described above has confirmed my belief that translating poetry could and should be studied as part of the general translators' training, despite the fact that the need for professional translators of poetry may seem to be in decline compared to the need for such professionals in other fields as previously explained. Translating poetry should not depend on a small number of poets who may be interested on their own accord to offer translations of their favourite poets' works 
to other language communities. Translating poetry can be studied and learnt provided that the student acquires a solid background knowledge in different translation theories as well as in prosody (versification), historical context, different styles and ways of use of lexis, grammar or syntax. Undoubtedly, the more practice the student has, the more fluent and creative the translation can become.

When commissioned by a publishing house or an organisation or a particular poet himself/herself to translate a poem or a collection of poems, the translator is usually given a certain deadline by which the translation has to be completed. This can also pose a challenge to make the translation as good as possible. Poets may spend months or even years re-drafting their works to express the particular nuance they wish to incorporate in the poem. Andrew Marvell also re-drafted this poem and the printed version differs from the manuscript drafts in imagery and some word choices (British Library, 18th Century Literature). Translators, unfortunately, do not have that luxury - they may have a couple of weeks or months to finalize the translation, to tune in with the poet, to convey the message and make it sound as if it were written in their mother tongue. For that reason, studying how to translate poetry may be an instrument in the translator's hands which can assist in tackling all the difficulties presented in this paper, and many others which can be foreseen or which may unexpectedly appear. 


\section{REFERENCES}

British Library. (2020, August 01). Retrieved from Discovering Literature: https://www.bl.uk/collection-items/an-early-manuscript-copyof-marvells-to-his-coy-mistress

www.bl.uk/restoration-18th-century-literature. (2020, August 03). Retrieved from British Library - Discovering Literature: www.bl.uk/ restoration-18th-century-literature

www.poetryfoundation.org/poems/44688/to-his-coy-mistress. (2020, May 07). Retrieved from poetryfoundation: https://www.poetryfoundation.org/ poems/44688/to-his-coy-mistress

Abrams, M. (2000). The Norton Anthology of English Literature (Seventh ed., Vol. 1). (M. G. Abrams, Ed.) New York. London: W.W.Norton \& Company.

Bakic, T. (2011, 01 03). okf-cetinje.org/endrju-marvel/ (Otvoreni kulturni forum). Retrieved from okf-cetinje.org: https://okf-cetinje.org/endrjumarvel/ (Otvoreni kulturni forum, postavljeno 03/01/2011)

Barnes, V. (2004). A Foreign Affair. Bantam.

dictionary.cambridge.org/dictionary. (n.d.). Retrieved from Cambridge Academic Content Dictionare: https://dictionary.cambridge.org/ dictionary/english/mistress

Gioia, D. (2015). http://danagioia.com/essays/american-poetry/poetry-asenchantment. Retrieved July 20, 2020, from danagioia.com.

Gioia, D. (2020, August 03). danagioia.com/essays/american-poetry/canpoetry-matter/. Retrieved from www.danagioia.com: http://danagioia. com/essays/american-poetry/can-poetry-matter/

Gioia, D. (n.d.). danagioia.com/essays/writing-and-reading/thirteenways-of-thinking-about-the-poetic-line. Retrieved from www.danagioa. com: http://danagioia.com/essays/writing-and-reading/thirteen-ways-ofthinking-about-the-poetic-line 
Lešić, Z. (2005). Teorija književnosti. Sarajevo: Sarajevo Publishing.

Miroux, F. (2010, December). Translating poetry: decoding meaning or recomposing harmony. (B.J.Epstein, Ed.) Other Words(36), pp. 96-108.

Venuti, L. (2011). Introduction: Poetry and translation. In Translation Studies (Vol. 4, pp. 127-132). Routledge.

Williams, J. (2013). The Palgrave Macmillan Theories of Translation. Palgrave Macmillan.

www.britannica.com/art/alexandrine. (n.d.). Retrieved from britannica. com: https://www.britannica.com/art/alexandrine 


\section{CORPUS ANALYSED}

Appendix 1

TO HIS COY MISTRESS

by Andrew Marvell (1621-1678)

Had we but world enough and time,

This coyness, lady, were no crime.

We would sit down, and think which way

To walk, and pass our long love's day.

Thou by the Indian Ganges' side

Shouldst rubies find; I by the tide

Of Humber would complain. I would

Love you ten years before the flood,

And you should, if you please, refuse

Till the conversion of the Jews.

My vegetable love should grow

Vaster than empires and more slow;

An hundred years should go to praise

Thine eyes, and on thy forehead gaze;

Two hundred to adore each breast,

But thirty thousand to the rest;

An age at least to every part,

And the last age should show your heart.

For, lady, you deserve this state,

Nor would I love at lower rate.

But at my back I always hear

Time's wingèd chariot hurrying near;

And yonder all before us lie

Deserts of vast eternity.

Thy beauty shall no more be found;

Nor, in thy marble vault, shall sound

My echoing song; then worms shall try

That long-preserved virginity,

And your quaint honour turn to dust,

And into ashes all my lust;

The grave's a fine and private place,

But none, I think, do there embrace. 
Now therefore, while the youthful hue

Sits on thy skin like morning dew,

And while thy willing soul transpires

At every pore with instant fires,

Now let us sport us while we may,

And now, like amorous birds of prey,

Rather at once our time devour

Than languish in his slow-chapped power.

Let us roll all our strength and all

Our sweetness up into one ball,

And tear our pleasures with rough strife

Through the iron gates of life:

Thus, though we cannot make our sun

Stand still, yet we will make him run.

(www.poetryfoundation.org/poems/44688/to-his-coy-mistress, 2020) 
Appendix 2

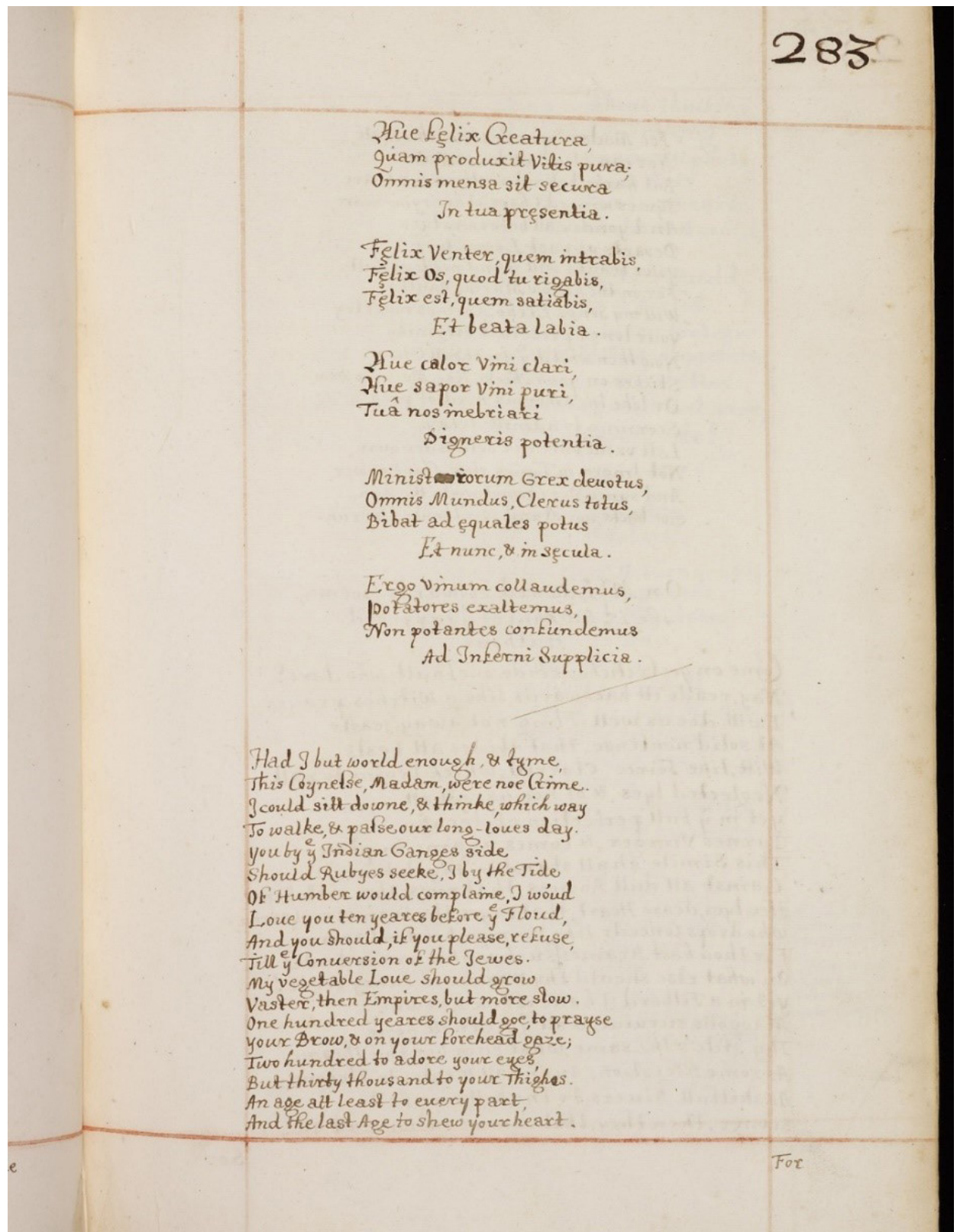

Copyright: (C) Bodleian Library, University of Oxford Held by Bodleian Library, University of Oxford Shelfmark: Bodleian Don.b.8. 
Appendix 3

STIDLJIVOJ MU DRAGANI

(translated by: Vesna Suljić)

Da imamo viška i svijeta i vijeka, Tvoja čednost, gospo, mogla bi da čeka.

O danima ljubavi mogli bismo sjesti I smišljati gdje i kako ih provesti.

Rubine kraj Ganga ti našla bi sebi; A ja bih uz Humber jadikov'o tebi; Ljubio te deset pretpotopskih ljeta A ti bi čekala, jer ti to ne smeta, Odbijala, ako to je želja tvoja, Do preobraćenja židovskoga soja. Ljubav bi moja tad k'o bilje rasla, Sporije i šire nego c'jela carstva; I sto bi ljeta prošlo da oči slavim Tvoje i na čelu ti svoj pogled stavim; I po dvjesto da se svakoj dojci divim, A hiljada triest' za ostalo da živim; Po vijek cijeli za sve to što ti imaš, A posljednjeg dana da mi srce predaš. Jer to, gospo draga, zaslužuješ i ja Te volio manje od tog ne bih, nikada.

$\mathrm{Al}^{\prime}$ za sobom čujem te krilate vrle Vremenske kočije što sve brže hrle; I svud pred nama i oko nas se grade Pustinje prave nepregledne vječnosti.

Ni ljepote tvoje više neće biti;

Ni u mramornoj tvojoj škrinji niti odjek moje pjesme; crvi da se slade Predugo čuvanom tvojom nevinosti I tvoja će smjerna čast u prah propasti, A u pepeo otići sve moje strasti;

Grob je mjesto skriveno i stvarno krasno, Al' se niko tu ne grli, to je jasno. 
Stoga, gospo, dok boje mladosti tvoje $\mathrm{K}$ 'o jutarnja rosa na licu ti stoje, I dok ti željna duša vatreno diše I kroz svaku poru strastveno uzdiše, Razonodimo se dok imamo dana I k'o zaljubljene grabljivice s grana proždrimo u jednom dahu svoje dane mjesto da nas vrijeme gricka natenane. Skupimo u loptu silu svoje strasti, I zavrtimo se u toj svojoj slasti, Skršimo željezne okove života

Snagom koju daje ljubavi divota:

Zato velim, iako sunce stajati

Za nas neće, natjerajmo ga trčati. 
Appendix 4

NJEGOVOJ SRAMEŽLJIVOJ LJUBAVNICI

(translated by: Tanja Bakić)

Prostora samo da nam je više i vrem'na,

Žudnja tvoja, Damo, ne bi bila sramna.

Ja i ti sjedjeli bismo i mislili kako

Da udvoje šetamo i ljubavimo lako.

Ljubav ti bi našla u indijskom Gangu,

Dok u Hamberu ja tješio bih svoju tugu.

A odbijanje tvoje nek se ne krati

Sve dok svaki Jevrej se ne preobrati.

Zrno moje ljubavi narašće - biće veće

I od carstva samog, ali to polako će.

Sto čitavih godina ja bih hvalio

Tvoje oči i u tvoje čelo gledao.

Dvjesta godina da mi je da grudi ti grlim,

I trideset hiljada narednih da na njih pohrlim.

Za svaki dio tebe meni je po jedno doba

A zadnje kad dođe, srce tvoje će da se proba.

Jer ti, Damo, zaslužuješ ovu državu,

Tebi ja dao bih svu na svijetu slavu.

No, nekad ja ipak osjetim s leđa

Života brzog gdje bliži se međa.

I pred nama vidim onda ogromne

Vječnosti pustinje svuda prostrane.

Ljepota tvoja jednoga dana iščeznuće

A iz mermernoga svoda tvoga neće

Čuti više se moj poj: crvi će zagmizati,

I tvoju će dugo čuvanu nevinost proždrati.

Od poštenja tvog starinskog ostaće prašina,

A od žudi moje u pepelu jedna tišina.

Grob je mjesto tako mirno i lično,

Ali nikom tamo ne može biti dično.

Zato, hajde sada dok sjekira mala

U krilu klati ti se k'o rosa tek što je pala,

Dok duša tvoja u žudu se znoji

U svakoj pori, plameno dok ona se gnoji, 
Daj da uživamo dok još možemo, Kao ptice grabljivice zaljubljeni budimo, Kao ptice što ih vrijeme polako proždire Dok čežnju oni svoju odlaganjem more.

Sunce iako ne možemo zaustaviti,

Da trči barem možemo ga natjerati. 
